\title{
Concordanțe romanice și convergențe balcanice în dialectele româneşti sud-dunărene din perspectiva geografiei lingvistice
}

\author{
Manuela Nevaci \\ Institutul de Lingvistică \\ "Iorgu Iordan - Alexandru Rosetti" / Universitatea din Bucureşti \\ elanevaci@yahoo.com
}

Articolul nostru are în vedere evidențierea concordanţelor lingvistice ale dialectelor româneşti sud-dunărene (aromân, meglenoromân, istroromân) din Albania, Grecia, R. Macedonia, Croaţia şi România din perspectiva concordanțelor cu elementele romanice şi a convergențelor cu cele balcanice.

Cuvinte cheie: geografie lingvistică, dialectologie, aromân, meglenoromân, istroromân

1. În lucrarea de față ne propunem să subliniem asemănările lingvistice ale dialectelor românești sud-dunărene (aromân, meglenoromân, istroromân) vorbite în Albania, Bulgaria, Croația, R. Macedonia de Nord și Grecia din perspectiva elementelor romanice și balcanice.

Vom lua în considerare aspectele lexicale (câmpul lexical al numelor de rudenie), din punctul de vedere al contactului lingvistic cu limbile balcanice (albaneza), precum și elementele romanice care definesc aceste dialecte istorice ale limbii române. Expunerea noastră se bazează pe tema mai largă a relației dintre genealogic (trăsături romanice moștenite de română din latină, vorbind de concordanțe cu limbile romanice) și areal (convergențe între dialectele limbii române, aromân și meglenoromân cu limbile vorbite în zona balcanică).

2. Dialectele românești sud-dunărene (aromân, meglenoromân și istroromân) reprezintă supraviețuiri ale romanității din Imperiul Roman de Răsărit, care, la sfârșitul secolului al III-lea d. Hr., și-a fixat granița de nord pe Dunăre. Conservarea romanității sud-dunărene se explică prin faptul că latina a fost, până în secolul al VII-lea, limba oficială a Imperiului Roman de Răsărit și, de asemenea, prin permanentele contacte dintre populația romanizată din sudul Dunării cu cea din nordul Dunării. În provinciile romanizate din nordul și din sudul Dunării s-a format un continuum romanicum, întrerupt o dată cu stabilirea slavilor în sudul Dunării începând cu secolul al VI-lea (cf. Saramandu 2004: 71-72). Prezența în sudul Dunării a românitătii - care, începând cu secolul al X-lea, apare sub numele de vlahi - este amplu atestată în surse latine și bizantine din secolele VI-XV. 
Dialectele românești sud-dunărene se vorbesc astăzi într-un spațiu vast: dialectul aromân (în Grecia, Albania, R. Macedonia de Nord, Bulgaria, România), dialectul meglenoromân (în Grecia, R. Macedonia de Nord, România, Turcia europeană), dialectul istroromân (Peninsula Istria, Croația, Trieste, Italia).

Cercetarea noastră se bazează pe: Atlasul lingvistic al dialectului aromân, vol. II (Nicolae Saramandu, în colaborare cu Manuela Nevaci), Editura Academiei Române, București, 2019 (sub tipar); Atlasul lingvistic român pe regiuni. Sinteză $-A L R R$. Sinteză, vol. III (coordonator: Nicolae Saramandu), Editura Academiei Române, București (autori: Mihaela Mariana Morcov, Manuela Nevaci, Irina Floarea, Daniela Răuțu, Carmen-Ioana Radu, Mara Iuliana Manta, Ionuț Geană); Sprach- und Sachatlas Italiens und der Südschweiz (AIS) ${ }^{1}$, Karl Jaberg und Jakob Jud, Zofingen, Ringier, 1928-1940 (vol. I); L'Atles Lingüístic del Domini Català (ALDC), Lídia Pons i Griera, Joan Veny, Institut d'Estudis Catalans, Barcelona, 2001-2018, vol. III, Familia.

În Atlasul lingvistic al dialectului aromân (ALAR) este publicat integral materialul cules, prezentat pe hărți lingvistice și în liste cu material necartografiat (MN), însoțite de note. În anchetele de teren s-a folosit Chestionarul noului atlas lingvistic român (2543 de întrebări), făcând posibilă compararea materialului dialectal aromânesc cu cel cuprins în atlasele regionale ale dacoromânei.

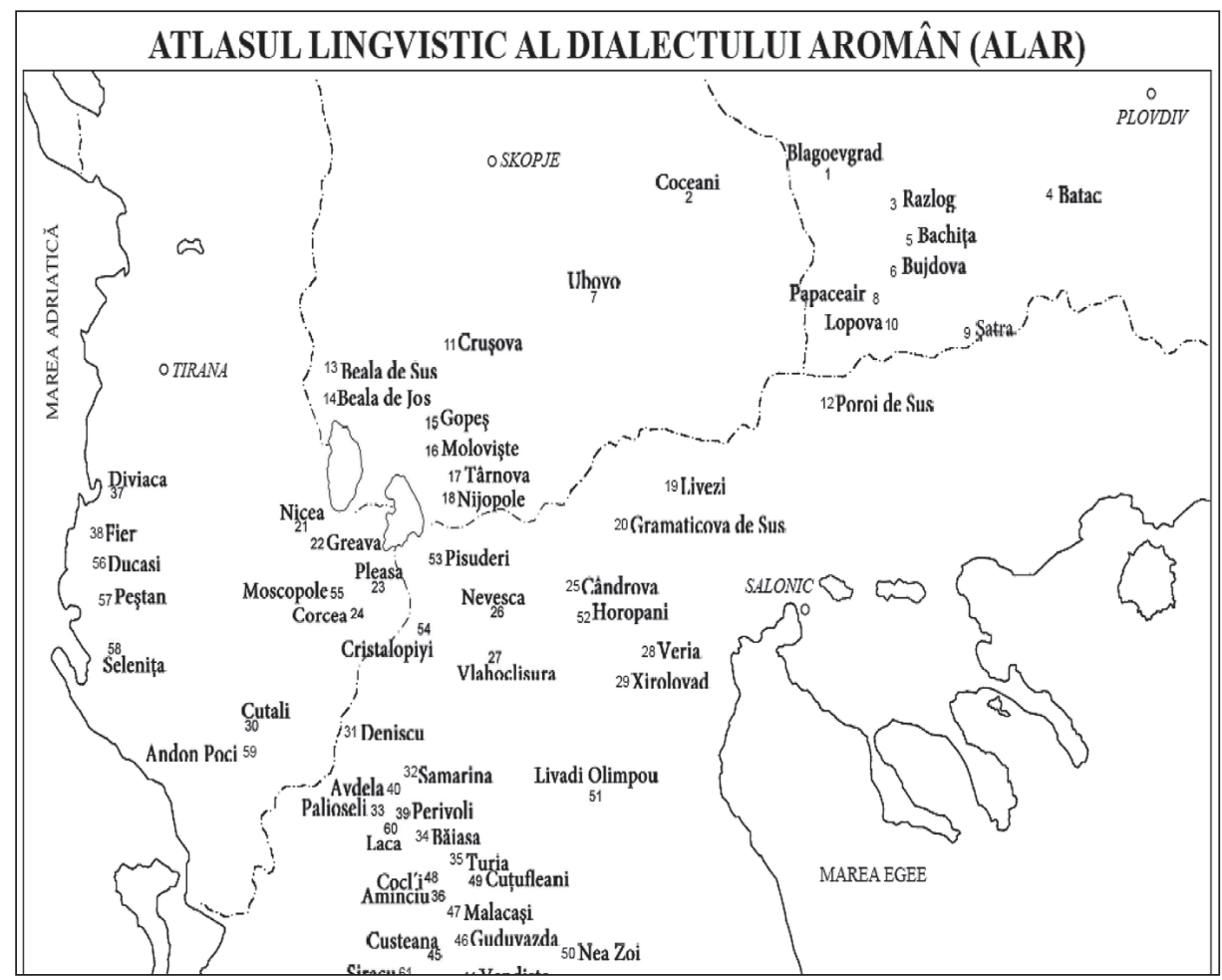

1 Mulțumesc colegei mele de Universitatea din Torino, Federica Cugno, pentru informațiile referitoare la consultarea AIS. 
Volumul al II-lea al atlasului, pe baza căruia se întemeiază lucrarea de față, cuprinde răspunsurile la capitolul „Familia” (la care se adaugă „Casa”, ,Curtea”) din Chestionarul noului atlas lingvistic român (întrebările 464-989).

Rețeaua de anchetă are 61 puncte de anchetă în Bulgaria, R. Macedonia de Nord, Grecia, Albania (32 în Grecia, 12 în Albania, 9 în R. Macedonia de Nord, 8 în Bulgaria).

Pentru compararea materialului dialectal al aromânei cu materialul dialectal al dacoromânei am luat în discuție aceiași termeni din câmpul lexical nume de rudenie din Atlasul lingvistic român pe regiuni. Sinteză - ALRR. Sinteză, Vol. III.

3. Concordanța are bază genetică și se stabilește, de obicei, între limbi care au întrerupt contactul lingvistic direct (ex. între dacoromână și dialectele italiene meridionale - e cunoscut studiul lui Iorgu Iordan (1923-1928) în acest sens). Prezența concordanțelor se constată:

a) la nivel sintactic;

b) în principiile structurii morfologice;

c) la nivel lexical.

Convergențele apar în urma unei evoluții pe baza vecinătății geografice și a contactului direct între vorbitori. Contactul dă naștere imitației și imitația dă naștere convergenței lingvistice.

Concordanțele cu limbile romanice. Vom analiza în articolul nostru modul de răspândire a inovațiilor lingvistice pornind de la constatările lui Matteo Bartoli, care a caracterizat ariile lingvistice pe baza relației element inovator - element conservator și a fixat atât punctul de plecare (în spațiu) al inovațiilor cât și vechimea inovatiilor.

M. Bartoli a stabilit patru norme areale, din care una este cea a ariei laterale. Ariile laterale sunt mai conservatoare și se opun ariilor centrale, care sunt mai inovatoare. În cadrul Romaniei, arii laterale sunt Iberia și Dacia, față de Galia și Italia, care formează o arie centrală (cf. Bartoli 1925 apud Nevaci 2018 (coord.): 18-19).

Vom ilustra teoria ariilor laterale a lingvistului italian cu exemple din limba română, luând în considerație atât româna vorbită în nordul Dunării (dialectul dacoromân), cât și româna vorbită în sudul Dunării, ilustrată prin dialectele aromân, meglenoromân și istroromân.

Convergențe lingvistice româno-albaneze. În ceea ce privește istoria limbii române, studiul concordanțelor lingvistice româno-albaneze are în vedere trei aspecte importante: elementul autohton (stabilit prin comparația cu albaneza, foarte probabil continuatoare a ilirei; elementul latin comun albanezei - datorat adstratului în această limbă - și limbii române - datorat stratului -; împrumuturile directe din albaneză în dialectele românești sud-dunărene.

\section{Termeni de rudenie în dialectul aromân în cadru romanic și balcanic}

Chestiunea 496. VĂR 'COUSIN'

În ALAR II, harta 297 sunt ocurente formele: cusurín; cusurín ver; prot cusurín și ver. 
cusurín s. m. 'grad de rudenie între copiii persoanelor care sunt frați și surori' $<$ lat. consobrinus. Dialectul aromân nu a păstrat sensul de 'văr primar'. Pentru acest sens s-au construit sintagmele cusurín ver < lat. (consobrinus) vērus și prot cusurín < prot (< gr. $\pi \rho \omega ́ \tau o \varsigma)+$ cusurín (pentru evoluția semantică a lui prot, cf. sp., cat. dial. primo) (REW 9262).

Din răspunsurile înregistrate în h. 297, se observă coexistența termenilor cusurín / cusurín ver/ prot cusurín/ ver în localitățile Coceani din R. Macedonia de Nord și Fier din Albania. Aceeași este situația în dialectul dacoromân, unde alături de veri, apar: veri bunil veri întâi / veri primári.

Cusurín e un termen aproape general răspândit, slab concurat de ver în opt localități din Bulgaria și R. Macedonia de Nord.

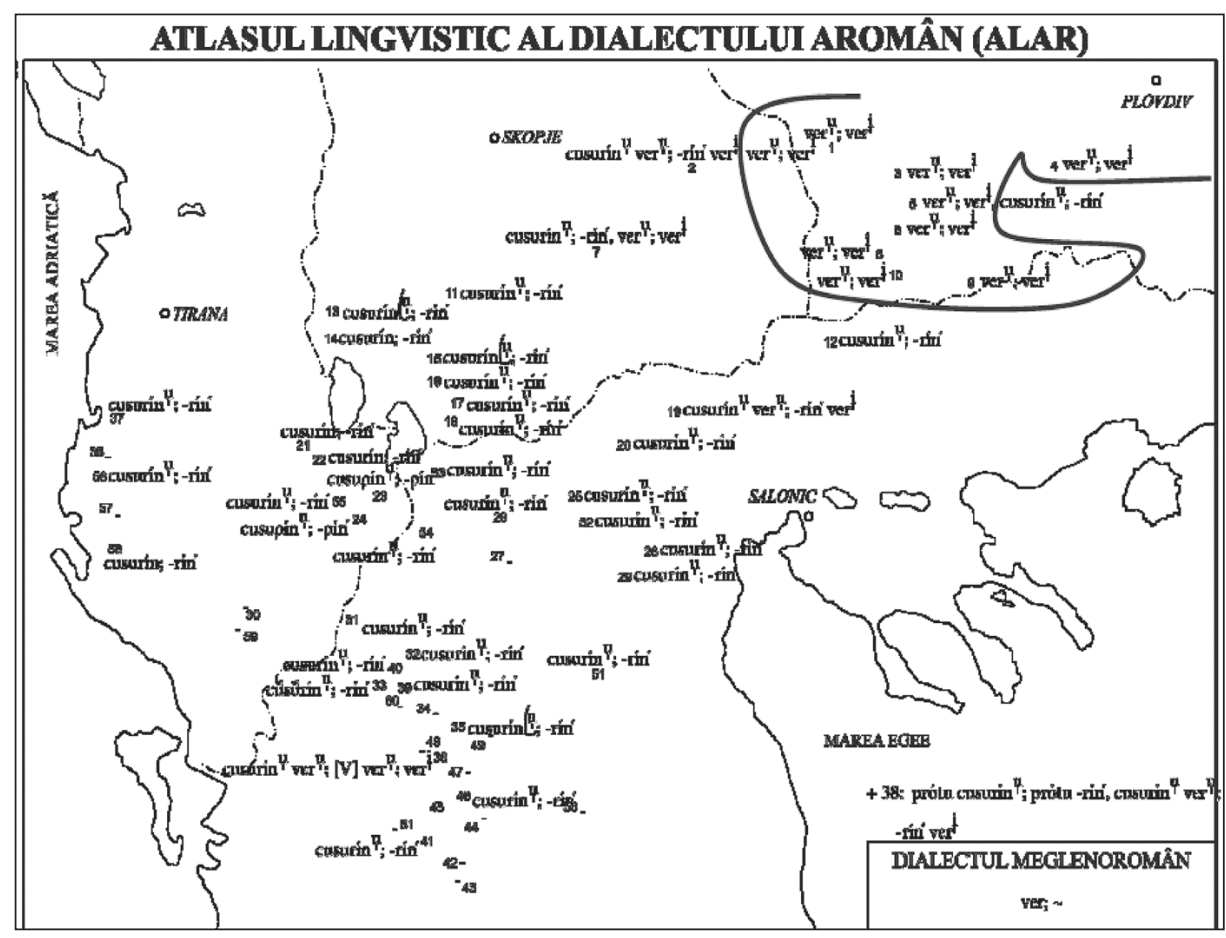

Pentru atestarea termenului în dacoromână, vezi h. 355 din ALRR. Sinteză III (autorul hărții: Mihaela Morcov)

În alb. kushëri ‘văr, fiul unchiului (pe linie maternă sau paternă), fiul mătușii (pe linie maternă sau paternă' provine tot din latină-<lat. consobrinus. Termenul este atestat și în dalmată, dialectal în italiană, în retoromană (sobor) și în spaniolă și portugheză (sobrinus) (Vătășescu 1997: 106). Referitor la atestarea acestui termen în dialectul aromân și în limba albaneză, Grigore Brâncuș afirmă: „Există numeroase cazuri de cuvinte vechi, de proveniență latină ori autohtonă, care au fost reamenajate fonetic, uneori și semantic, după corespondentele albaneze, ceea ce reprezintă un aspect important al bilingvismului aromânilor din Albania. Astfel cusurin 'văr' (disociat din lat. consobrinus verus) coexistă cu cușuri, cușeari, 
după alb. kushëri ; var. cu ș e folosită numai la vocativ : cușuri, ̌u ńerdzi? 'vere, unde mergi?' (Capidan 1932), deci reamenajarea cuvântului s-a produs în limba vorbită". (Brâncuș 2009: 14).

ver s. m. 'grad de rudenie între copiii persoanelor care sunt frați și surori' < lat. (consobrinus) vērus. Termenul e atestat și în dr. văr, megl. ver. În istr. veru 'adevărat'. cf. it. sp., port. vero, prov., cat. ver, v. fr. voir. Sensul etimologic s-a păstrat în dialectul istroromân (DER s.v.).

Relevăm conservarea în dialectul aromân a termenului latinesc consobrinus, care nu mai există în dacoromână. În Romania occidentală se păstrează latinescul consobrinus, concurat de lat. primus, după cum observăm în AIS, harta 24 și în ALDC, harta 515:
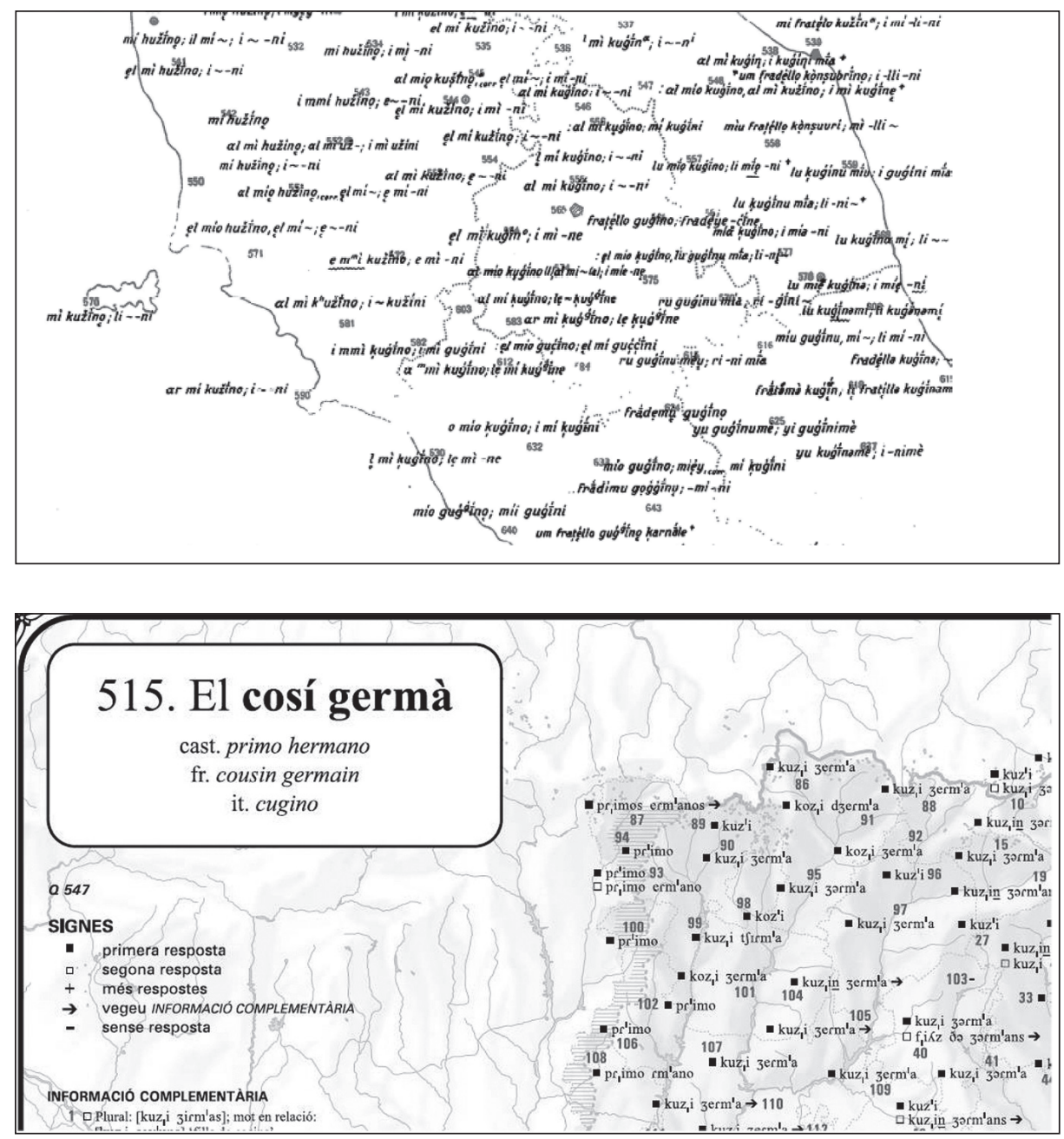

Chestiunea 548. NAȘĂ

ALAR II, harta 343: núnă; núnă nuícă; cumbáră. 
núnă s.f., 'soția nașului; femeie care cunună sau botează'. Forma aceasta este întâlnită și în dacoromână și în meglenoromână: núnă. Cuvântul provine din lat. nonna 'femeie bătrână', formă feminină a substantivului nonnus (Pușcariu 1905, 1207; REW 5817). În latină era folosit ca termen de adresare către persoanele în vârstă, termenul provenind probabil din vorbirea copiilor, reminiscență a lui nana, întâlnindu-se la nivel romanic, într-o arie laterală în: sard. nonna 'nașă', apul. nunna 'naşă', siciliană nunna.

Núnă e termenul general răspândit în dialectul aromân, fiind dublat înt-o singură localitate din Grecia, Cristalopiyi de cumbáră 'cumătră', de la cumbár <

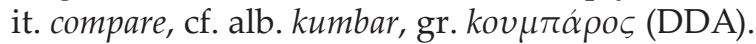

Atât nună cât și cumbară sunt atestate și în albaneză (Vătășescu 1997: 113). În timp ce în aromână nună e moștenit, în albaneză e un împrumut din latină.

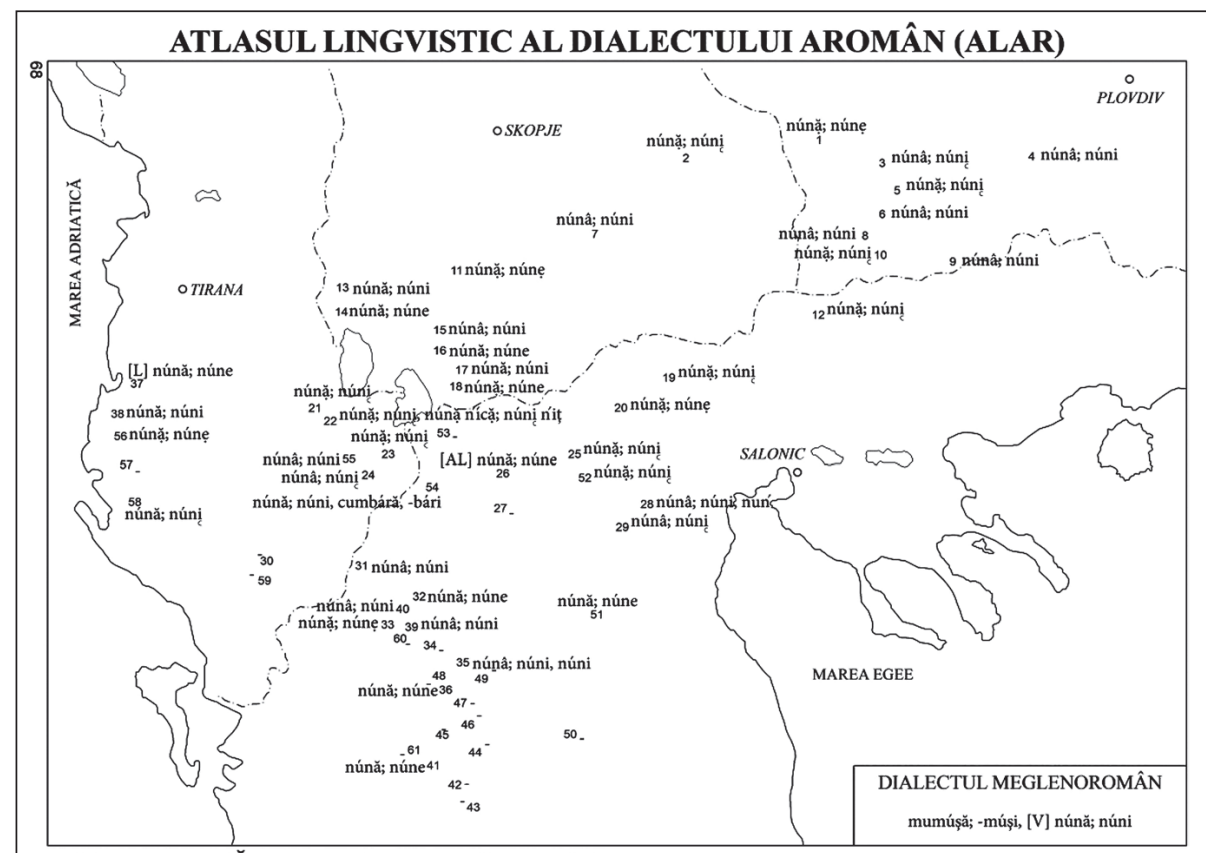

HARTA 343. NAŞĂ, pl.'marraine (au baptême)' [548]

Termenul nună este atestat și în dacoromână, într-o arie largă (Vezi Nevaci 2009: 161).

În sudul Italiei este ocurent termenul it. cumare, cu variantele sale fonetice, concurându-1 pe mult mai răspânditul nunna (nonna) (vezi AIS, harta 36): 


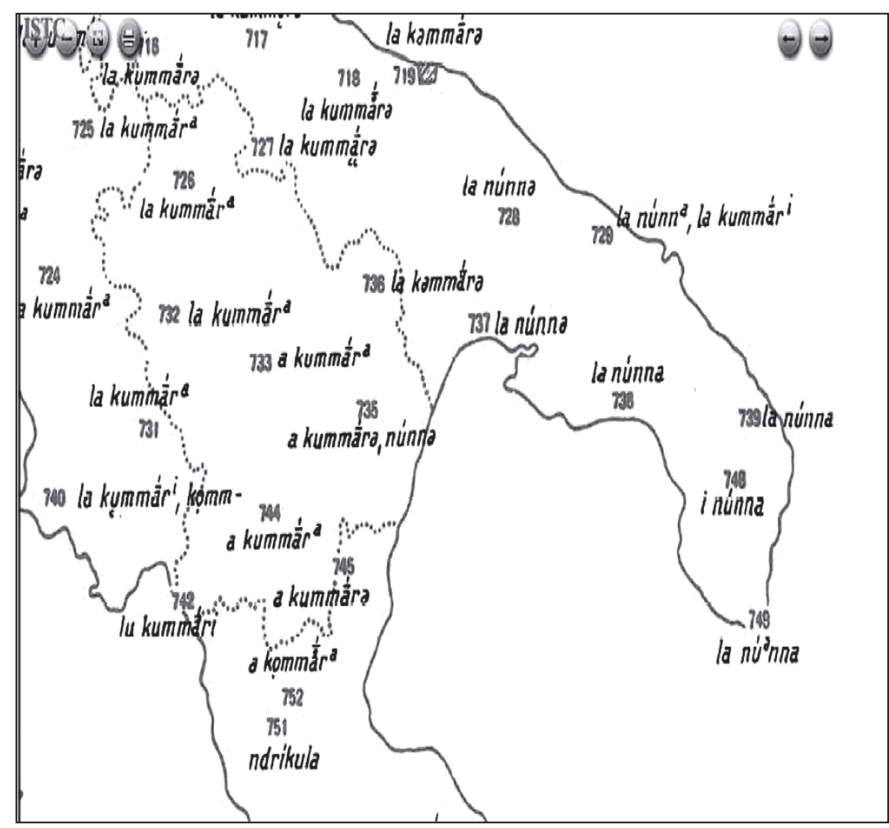

Chestiunea 553. FIN ${ }^{1}$

În ALAR II, harta 345 sunt ocurente formele: h'ilinn; cumbár (cumbârîc); pitiồun.

E interesant termenul h'il'ín, s.m., cunoscut cu sensul de 'fin considerat în raport cu nașii săi (de botez sau de cununie)' < lat. *filì̄anus, format ca derivat de la baza filius (ㄷ․ și alb. fijan, it. figliano 'copil alăptat de doică'). h'il'ín este general răspândit în graiul grămostean. Este ocurent într-o arie nordică, la fărșeroții din Albania, sub influența termenului din albaneză care întărește prin împrumutul său din latină, fijan < lat. *filianus, termenul moștenit de dialectul aromân.

Ceilalți fărșeroți folosesc termenul cumbár (s.m). Formează o arie extinsă, alături de derivatul cumbâríĉ la fărșeroții din Grecia și la pindeni. Termenul cumbár a pătruns din latină în greacă și în albaneză, de unde a intrat și în dialectul aromân (vezi supra cumbară).

pitiĝ́n, termen neatestat în DDA este înregistrat pentru prima dată în ALAR II cu sensul 'fin' la fărșeroții din Albania și din Grecia (graniță cu Albania), localitățile Selenița și Cristalopiyi. 


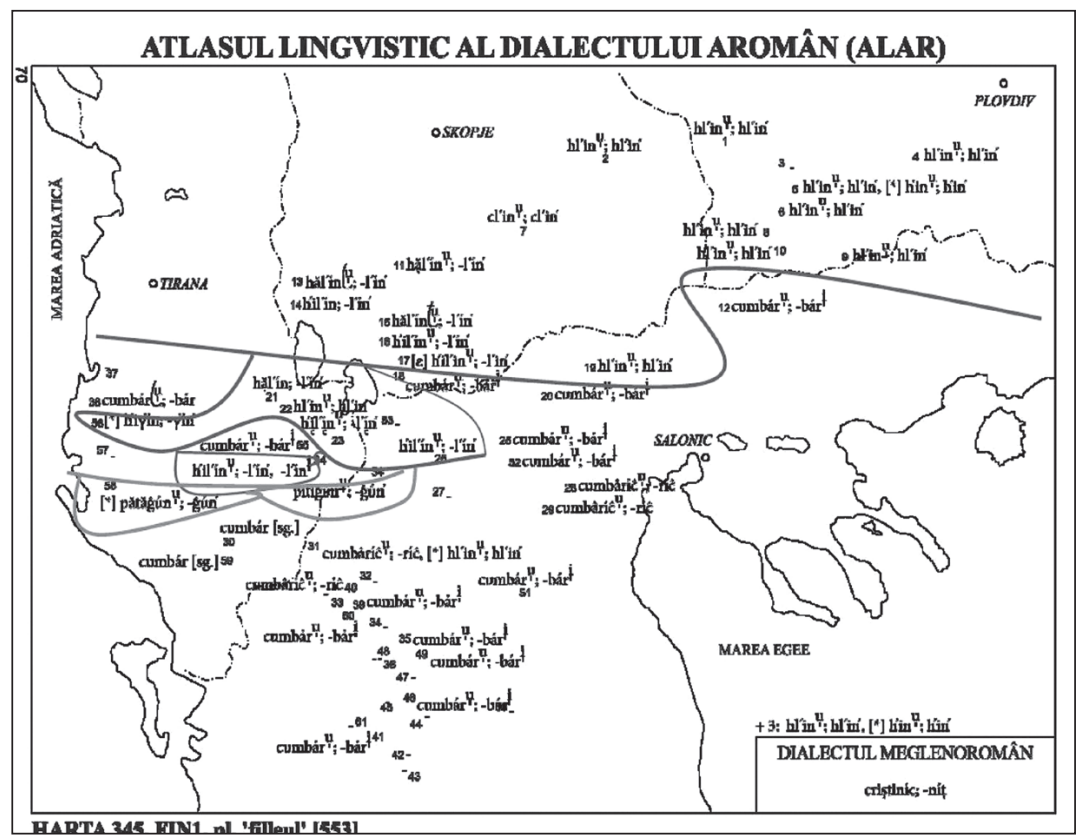

Pentru formele din dacoromână ale termenului FIN, vezi harta 400 din ALRR. Sinteză III (autorul hărții: Manuela Nevaci).

Termenul cumbár e atestat în dialectele italiene de centru și sud, păstrat din latină (ex.: kumbariedda, kummarella), așa cum rezultă din AIS, Harta 37:

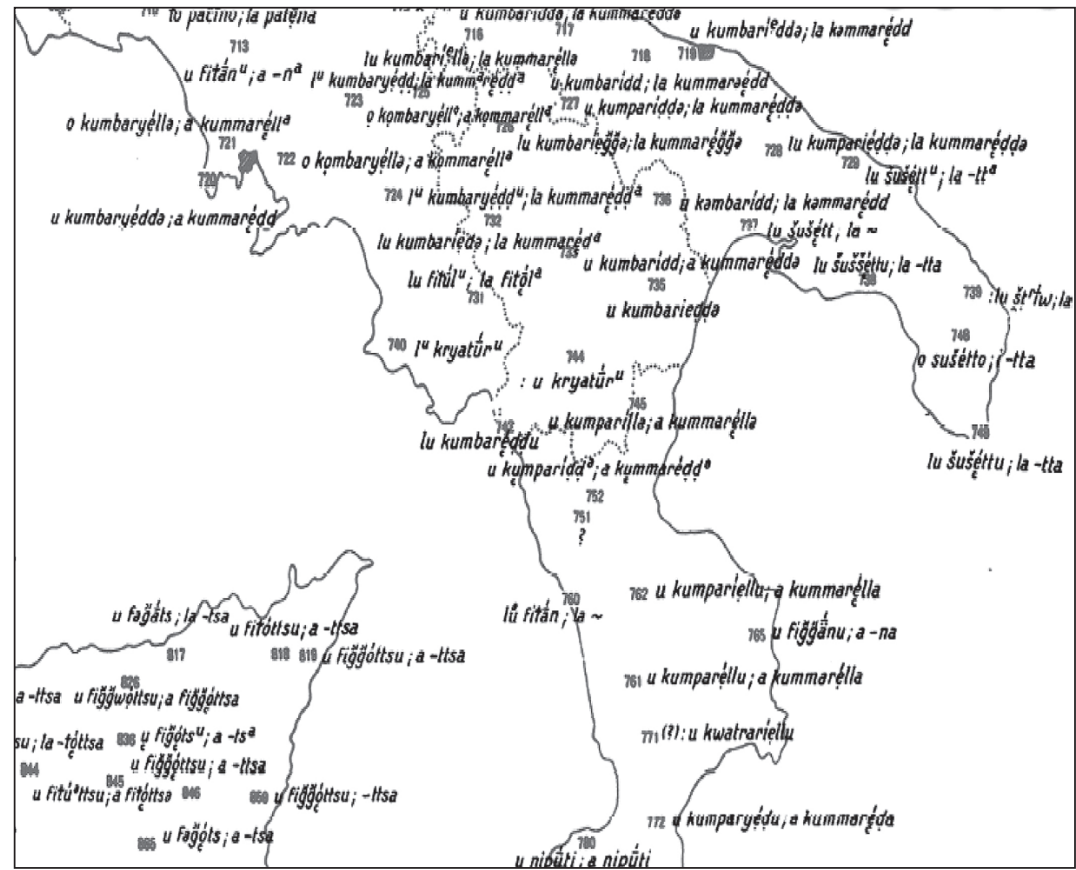


Termenul h'il'ín, moștenit din latină a fost păstrat și în provensală: felen 'nepot, ginere' < lat. *filēnus, așa cum rezultă ALDC, harta: 489:
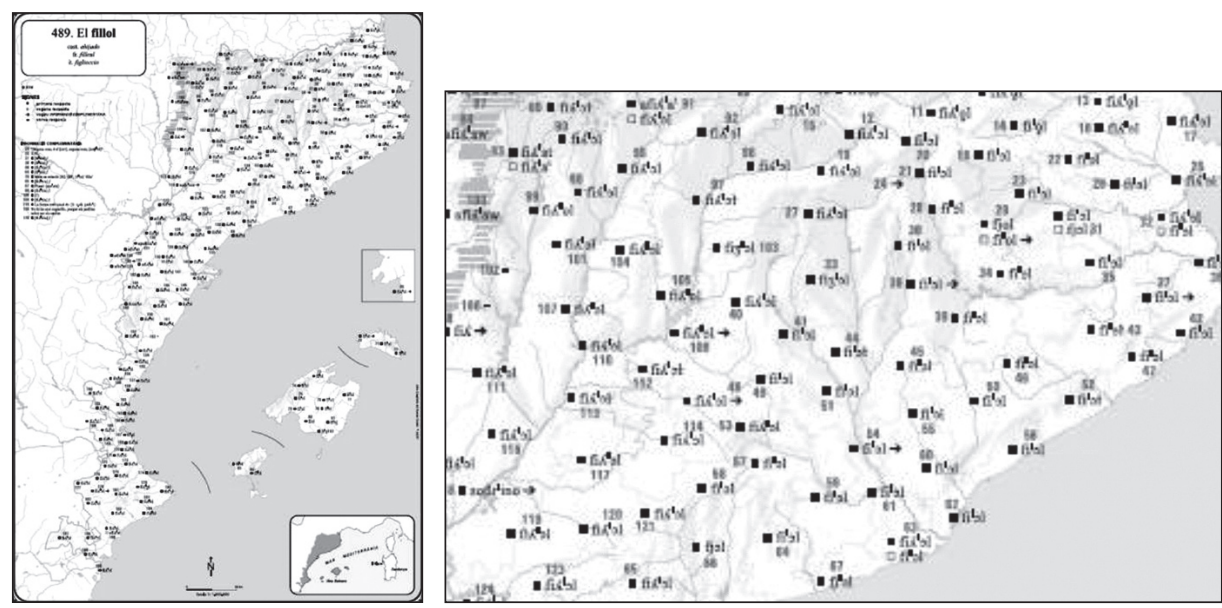

ALDC, harta: 489

Chestiunea 464. MAMĂ

În ALAR II, harta 275 sunt înregistrate formele: múmă, mámă, dádă, átă; nắnă. Semnalăm și forma mánă < gr. $\mu \alpha ́ v v v \alpha$, formă atestată la grămostenii din Bulgaria și la pindeni (în Grecia), precum și forma prescurtată, fără formă de plural, mă, cf. alb. më (DDA), atestată la grămostenii din Bulgaria.

múmă 'femeie considerată în raport cu copiii ei' < lat. mammanae (DDA, sv. mumă) este termenul care formează o arie bine conturată în graiul pindean (Grecia). Este concurat de mamă, dadă, ată, nănă.

mámă, s. f. femeie considerată în raport cu copiii ei < lat. mamma, e atestat în special ca răspuns dublu, în majoritatea graiurilor. Termenul e atestat în dr., mr., megl. mamă. Creație expresivă, probabil continuarea directă a lat. mamma (Pușcariu 1905: 1019; REW 5307). Este cuvânt infantil, de uz foarte general, bazat pe ideea de 'hrană' sau 'persoană care procură hrana'; cf. v. gr. $\mu \alpha \dot{\alpha} \mu \mu \alpha$, ngr. $\mu \alpha \dot{\alpha} \mu \alpha$ alb. mëmë, sl. (bg., sb., cr., rus.) mama, it. mamma, fr. maman etc. Continuarea lat. mamma pare să se demonstreze prin mr. mămos 'care are gușă' (DER).

dádă 'bunică', cf. srb. dada, alb. dadë, tc. dadı. Formează o arie relativ extinsă la fărșeroți și grămosteni (Albania, Bulgaria, Grecia, R. Macedonia de Nord). DDA îl înregistrează cu sensul de 'mamă', păstrat în vorbirea fărșeroților. La fărșeroți, pentru sensul 'bunică din partea tatălui' se folosește termenul múmă, pentru sensul 'bunică din partea mamei', termenul dádă.

În ceea ce privește împrumutul ată, atestat în patru localități în Albania, dintre care una ca răspuns dublu, Grigore Brâncuș afirmă: „unele nume de rudenie vechi și adjective moștenite însoțite de un articol proclitic, variabil după gen și număr, au fost preluate în aromână cu aglutinarea articolului; de exemplu, alb. i atë 'tată' a intrat în graiul fărșeroților sub forma jată 'mamă' " (Brâncuş 2009: 16). Terminația substantivului în - $\breve{a}$, specifică femininelor a motivat schimbarea de gen și, implicit, a sensului: tată $\rightarrow$ mamă. 
Formele împrumutate din albaneză nắnă; nắne < al. nënë sunt atestate în două localități ale fărșeroților din Albania. Termenii átă și nắnă nu sunt înregistrați în DDA, fiind împrumuturi recente.

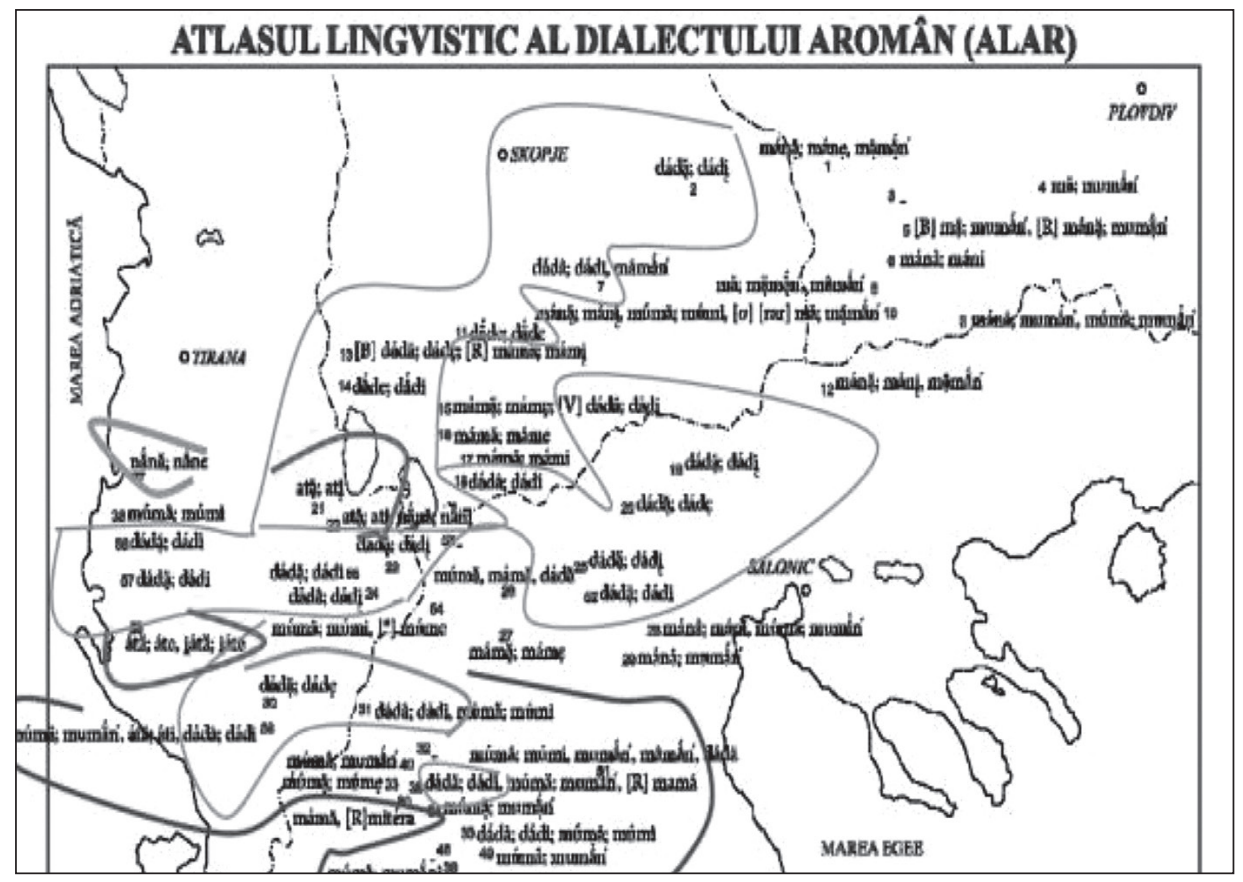

Deși forma forma prescurtată mă, atestată la grămostenii din Bulgaria, a fost pusă în legătură cu alb. më , constatăm în AIS, pe harta 8 că o astfel de formă este ocurentă în dialectele italienești din nord (cum este punctul 401, Piacenza):

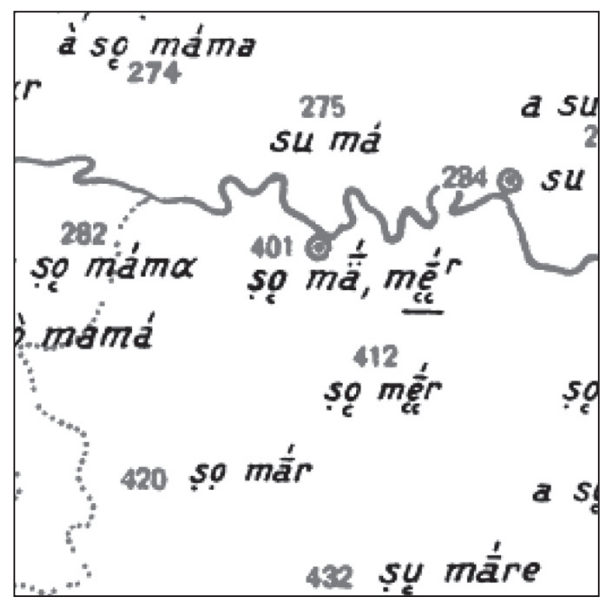

Concluzii. Din analiza efectuată rezultă situația din româna nordși sud-dunăreană, continuatoare a romanitătii orientale. ALAR și ALRR. Sinteză permit, pentru prima oară, delimitarea unităților dialectale din aromână și, respectiv, dacoromână, în perspectivă spațială romanică. Acesta este un progres important în domeniul geografiei lingvistice.

Concordanțele lexicale stabilite $\mathrm{cu}$ limbile romanice occidentale pun în evidență faptul că româna reprezintă o arie laterală în cadrul Romaniei (vezi chestiunile 496. $V \breve{A} R$ și 548. NAȘ $\breve{A})$, existând și situații în care avem unitate lexicală la nivel romanic (vezi chestiunile 553. FIN). 
Din analiza efectuată rezultă o imagine a situației actuale a dialectului aromân vorbit în spațiul balcanic: pe de o parte, îmbogățirea vocabularului cu termeni împrumutați din albaneză, greacă, slavă, turcă și, pe de altă parte, coexistența acestora cu termeni din fondul latin, moștenit al aromânei.

Raportate la dacoromână, dialectele românești sud-dunărene, prin elementele comune în domeniul lexicului de rudenie, pun în evidență caracterul unitar al limbii române vorbite în nordul și în sudul Dunării.

\section{Bibliografie:}

Bartoli, Matteo (1925). Introduzione alla neolinguistica, Genève: L.S. Olschki.

Brâncuş, Grigore (2009). Raporturi lingvistice aromâno - albaneze, în Lucrările celui de al II-lea Simpozion Internațional de Lingvistică (editori, Nicolae Saramandu, Manuela Nevaci, Carmen Ioana Radu), Bucureşti: Editura Universităţii, pp. 11-20.

Capidan, Th. (1932). Aromânii. Dialectul aromân. Studiu lingvistic, Bucureşti: Imprimeria Națională.

DDA = Papahagi, Tache (1974), Dicţionarul dialectului aromân, general şi etimologic, ediția a doua augumentată, Bucureşti: Editura Academiei Române.

DER = Ciorănescu, Alexandru (1954-1966), Diccionario Etimológico Rumano, Tenerife: Biblioteca Filológica,Universidad de La Laguna.

Nevaci, Manuela (coord.) = Nevaci Manuela / Floarea, Carmen-Irina / Geană, Ionuț / Toroipan, Teodora (2018). Convergențe lingvistice balcano-romanice în dialectele românești sud-dunărene, Editura Universității din București.

Puşcariu, Sextil (1905). Etymologisches Wörterbuch der rumänischen Sprache. I. Lateinisches Element mit Berücksichtigung aller romanischen Sprachen, Heidelberg.

REW = Wilhelm, Meyer-Lübke (1911). Romanisches etymologisches Wörterbuch, Heidelberg: C. Winter.

Saramandu, Nicolae (2004/2008). Romanitatea orientală, Bucureşti: Editura Academiei Române (2004); La romanité orientale, Bucureşti / Tübingen: Editura Academiei Române / Gunter Naar Verlag (2008).

Vătăşescu, Cătălina (1997). Vocabularul de origine latină din limba albaneză în comparație cu româna, Bucureşti: Ministerul Educaţiei, Institutul Român de Tracologie. 


\section{Romance concordances and Balkan convergences in the Romanian dialects south-Danube from the perspective of linguistic geography}

This paper proposes to emphasise the linguistic similarities of South-Danubian Romanian dialects (Aromanian, Meglenoromanian, Istroromanian) from the perspective of Romance concordances and Balkan convergences. The lexical concordances established with the Western Romance languages highlight the fact that the Aromanian represents a lateral area in Romania (see questions 496. VĂR 'cousin' and 548. NAŞĂ 'godmother'); sometimes, there are situations of lexical unity in the Romance languages (see questions 553. FIN 'godson').

Key words: linguistic geography, dialectology, Aromanian, Megleno-Romanian, IstroRomanian 